
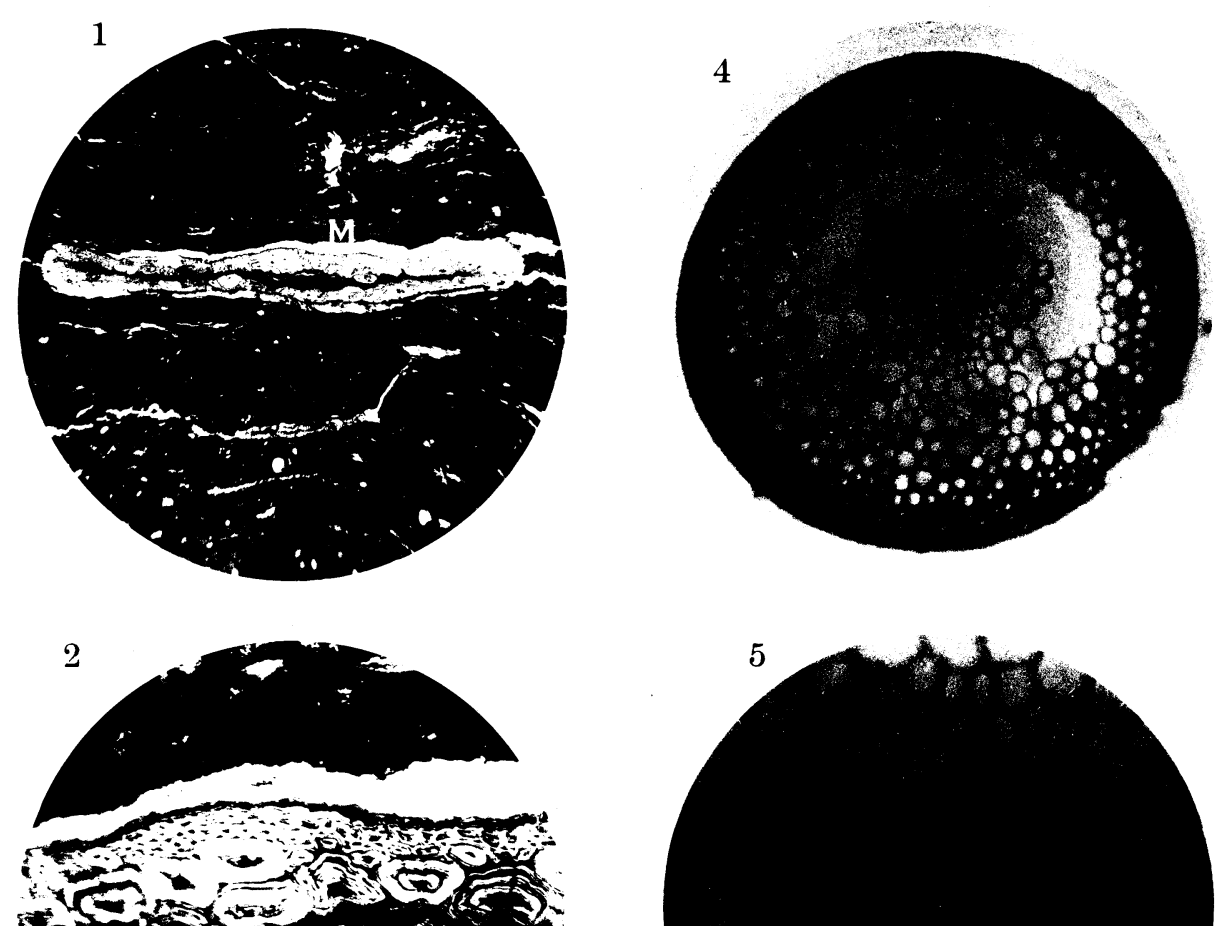

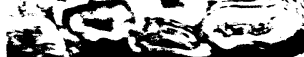
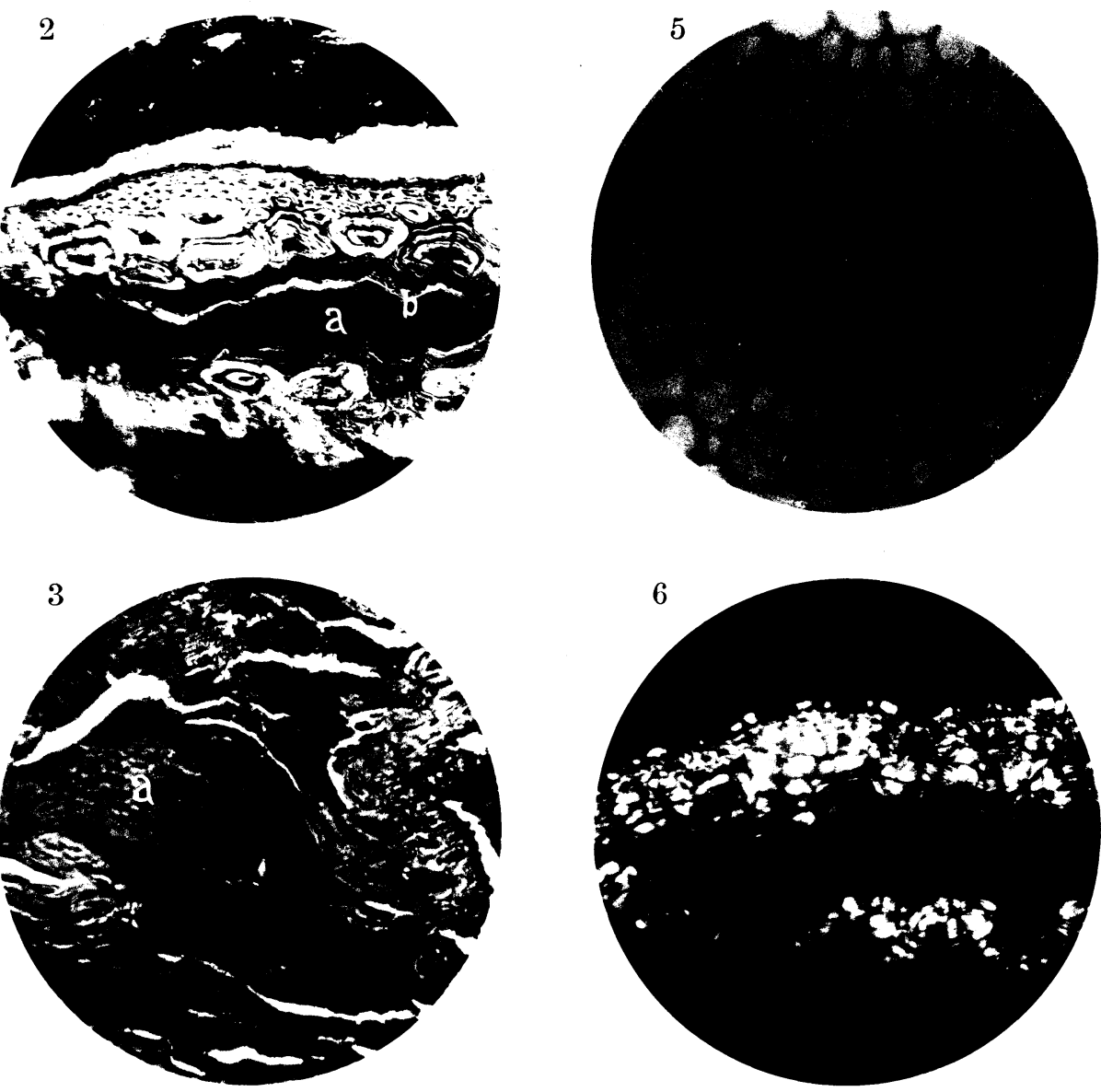

K. YASUI Photo.

YasUI-On a Tertiary Moss. 


\title{
Description of Internal Structure of Remains of a Tertiary Moss.
}

\author{
Contributions to Cytology and Genetics from the Department of \\ Plant-Morphology and of Genetics, Botanical Institute, \\ Faculty of Science, Tokyo Imperial University, No. 54.*
}

By

Kono Yasui.

With Plate $I$.

As far as I am aware the description on fossil mosses hitherto have been given on their external features as impression ${ }^{1,2,3 .)}$ External features are, however, sometimes missleading, especially in a lower plant with simple structures. As is now generally held, the internal structure is more reliable in this respect. So it seems not to be superfluous to give an internal structure of a specimen belonging to a fossil moss, although the nature of the present material is far from being satisfactory.

Several specimens, on which the present investigation is based, were found in lignite from Aichi coal field, Upper Tertiary in central Japan, and identified here as seta of a moss. A microphoto of a cross section of one of the specimen is shown in fig. I, M. It is in a com-. pressed state and measure about $\mathrm{I} \mathrm{mm} \times$ O.I $\mathrm{mm}$. The cells in the outermost layer, the epidermis, are small being ca. 5 to 9 micra in the tangential diameter. They are flattened due to compression, so that their cavities are hardly present. The cell wall of the epidermis is

* Articles concerning plant anatomy will be included hereafter in this series of publications.

I) Schimper, W. Ph. (1890) Handbuch der Paläontologie von Zittel, Abt. II Paläophytologie S. 74-75.

2) Seward, A. C. (1898) Fossil Plants. pp. 236-24r.

3) Potoniè, H. u. Gothan, W. (I92I) Lehrbuch der Paläobotanik. 2. Aufl. S. 36. 
dark brown under the microscope. Neither stomata nor trichome are observed on the epidermis.

In the cross section, there are two or three layers of small thick walled subepidermal cells of 5 to 15 micra in diameter. They are followed by one or two layers of large thick walled cells 30 micra or more in diameter; the length of these cells in longitudinal section measuring 70 to 120 micra. The wall of the latter is very thick measuring 5 to 12 micra. The cell wall of all these thickwalled cortical layers is light yellow under the microscope.

The central part of the cross section, as is shown in the fig. 2, a, is occupied with a tissue composed of hexagonal cells about 8 micra in their diameter. Fig. 3 is a microphoto of a slightly oblique cross section of another part of the same material. In this the central part of the section is shown in a better condition, though the preservation of the outer part very imperfect. Between this central tissue and sclerotic tissue above stated, there is a tissue of thin walled cells which are compressed badly, so that the details of structure are hardly recognizable. Besides about midway in the photo lying crosswise a distinct tissue layer of one or two cell thick, fig. $2, \mathrm{~b}$, is observed. In contrust to the badly preserved thin-walled tissue, this tissue layer is well preserved; the cell wall in this tissue is yellowish brown under the microscope. This is evidently the endodermis which divides the main mass of the tissue of the specimen into two parts, the outer cortical tissue and the inner central cylinder. We see in the photo that the outer part of the central cylinder is also badly preserved.

Now we can locate in the specimen, epidermis, cortex, endodermis and central cylinder, of which the cortex is differentiated into the outer thick walled tissue and the inner thin walled parenchymatous tissue, and the central cylinder consists of the central xylem and the outer badly preserved phloem. ${ }^{\text {1) }}$

The extremely simple structure of the xylem and the dimunitive

I) Veizey proposed the name "leptxylem" and "leptphloem" for the functional xylem and phloem of the sporophyte of mosses in his "On the anatomy and developemedt of the sporangium on the mosses" (Journal of Linean Society, Botany, Vol. 24, pp. 262-285, 1888). Xylen and phloen of higher plants and those of mosses are most probably not homogeneous to each other; still $I$ feel it is not necessary to adopt different term for both. We may use same term for both, just as we do with the terms "stem" and "leaf." 
size of the specimen are its characteristic features. Moreover, no indication of leaf-traces is observed.

There is no other plant organ known, whose structure is such as described above, than caulome of a certain group of mosses. For comparison a microphoto of a cross section of a capsular stalk or seta of a moss of common occurence, Polytrichum commune L., is given. The outermost cell layer is the epidermis, which is dark brown under the microscope. The tissue, inside the epidermis, consists of sclerotic cells though the cells of internal layers are smaller than that of the present fossil. The sclerotic tissue is followed by the inner cortical tissue which consists of thin walled parenchymatous cells. The central cylinder is externally bounded by an endodermis just as in the stem of the present fossil specimen.

Fig. 5 is a microphoto of the central part of the stem of the same specimen from which the fig. 4 was taken, with a higher magnification. It shows the tissue of the primitive xylem. The comperison of figs. 4 and 5 with fig. 3 will demonstrate the identity of structure of the central xylem of the fossil specimen and that of Polytrichum commune.

In Polytrichum of the present day the cell wall of the outer thick cortex as well as of the xylem is somewhat lignified, and has property of double refraction as the wall of the parenchymatous cell of highr plants.

It is noteworthy that this optical property is perfectly retained and exactly same manner in the cell wall of the present fossil specimen. Fig. 6, which is a microphoto of the same specimen from which fig. 2 was taken, but this was taken with crossed nicols, shows the phenomenon of double refraction clearly. The interference color of the wall of the cross section of the sclerotic cells between crossed nicols with the insertion of the gypsum plate (red I) in usual way, is yellow in the first and third quadrants, the subtraction color, and in the second and fourth quadrants blue, the addition color.

These coinsidense in their anatomical structutre and the optical behavior of the tissue, the smooth surface of the specimen having no trace of stomata and of appendage, and the lack of a leaf trace in the tissue, together with the diminutive diameter of the specimen in question lead us to the conclusion that the fossil specimen is a capsular stalk or seta of a moss belonging to Bryae. 
We refrain from giving the present specimen any specific name, chiefly because of the fragmental nature of the specimen as a plant body. However, it may be convenient to have a name of the specimen, as is costomary in fossil botany, simply for the purpose of the future reference. We may call it Bryotrichum ${ }^{1)}$ aichiense, as it was found in lignite from Aichi coal field.

The preservation of the thick walled cells in the cortex of the fossil moss is very prominent among other plant remains in lignite. The state of preservation is almost equally well, when compared with that of the spores and pollen grains occuring in the same section; and due to the compactness and the bright yellow color of the thick walled tissue, the moss cortex in lignite comes up more prominently than spores or pollen grains in the field of microscope.

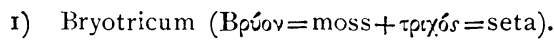

The expence for carrying out the study were partly defrayed out of the grant from the Department of Education, to the authorities of which my best thanks are due. My cordial thanks are also due to Professor K. Fujii for his encouragement and kind advice. She is also indebted to Professor B. Hayata for his kind advice.

November 1925 .

$$
\begin{gathered}
\text { Botanical Institute, Faculty of Science } \\
\text { Tokyo Imperial University. }
\end{gathered}
$$

\section{Explanation of Plate I.}

Fig. I. Microphoto of a cross section of the specimen. $\times 48$.

Fig. 2. Microphoto of a part of the same, highly magnified: $a$, xylem: $b$, endodermis. $\times 260$.

Fig. 3. Microphoto of a little oblique cross section of the same, specimen. The xylem tissue is clearly shown. $\times 260$.

Fig. 4. Microphoto of a cross section of a seta of Polytrichum commune L. $\times \mathbf{I} 20$.

Fig. 5. Microphoto of a part of the section from which the photo of fig. 4 was taken, highly magnified. $\times 345$.

Fig. 6. Microphoto of the same section from which the photo of the fig. 2 was taken, with crossed nicols. $\times 260$. 